DOI : https://doi.org/10.47828/iianaasian.v9i1.59

\title{
Kebijakan Desentralisasi dan Disparitas Pendidikan Lokal di Provinsi Sulawesi Tenggara
}

\author{
Obed Bida ${ }^{1}$ \\ ${ }^{1}$ Program Studi Ilmu Administrasi Negara Fakultas Hukum, Ilmu Sosial dan Ilmu Politik \\ Universitas Terbuka, Indonesia
}

\section{ART I CLE INFO}

\section{Article history}

Received 22/03/2021

Received in revised form 28/03/2021

Accepted 29/03/2021

\begin{abstract}
Paradoxically, decentralization policies can increase the participation and effectiveness of education services, but in the context of public policies it can also lead to educational disparities in society. This research was conducted to explain educational disparities in the perspective of decentralization policies as part of a public problem. This research method uses an interactive qualitative approach with data collection techniques through observation, document study and in-depth interviews and is analyzed using Spradley data analysis. The results showed that education policies in the regions did not create a balance, but instead opened up space for educational disparities in society, through the spatial and structural approach policy patterns. The dynamics of the education policy process are reflected in the contestation of the structural and political elites which tend to interfere with the efficiency, effectiveness and professionalism of education management. Local governments are often trapped in political interests and always place "elite capture" in decision making. Thus limiting the space for community participation and opening up spaces for educational disparities between central and periphery areas
\end{abstract}

Keywords: Decentralization policies, political systems, educational disparities

\begin{abstract}
Abstrak
Secara paradoks kebijakan desentralisasi dapat meningkatkan partisipasi, dan efektivitas layanan pendidikan, akan tetapi dalam konteks kebijakan publik ternyata juga dapat menyebabkan disparitas pendidikan di masyarakat. Penelitian ini dilakukan untuk menjelaskan disparitas pendidikan dalam perspektif kebijakan desentralisasi sebagai bagian dari masalah publik. Metode penelitian ini menggunakan pendekatan kualitatif interaktif dengan teknik pengumpulan data melalui observasi, studi dokumen dan wawancara mendalam dan dianalisis dengan menggunakan analisis data spradley. Hasil penelitian menunjukkan bahwa kebijakan pendidikan di daerah ternyata tidak menciptakan keseimbangan melainkan membuka ruang terjadinya disparitas pendidikan di masyarakat, melalui pola kebijakan pendekatan spasial dan pendekatan struktural. Dinamika proses kebijakan pendidikan tercermin pada kontestasi elit struktural dan elit politik yang cenderung mengganggu efisiensi, efektivitas dan profesionalisme pengelolaan pendidikan. Pemerintah daerah sering kali terjebak pada kepentingan politik dan senantiasa menempatkan "elite capture" dalam pengambilan keputusan. Sehingga membatasi ruang gerak partisipasi masyarakat dan membuka ruang disparitas pendidikan antara daerah sentra dan daerah pinggiran.
\end{abstract}

Kata kunci: Kebijakan desentralisasi, sistem politik, disparitas pendidikan 
*)Penulis Korespondensi

E-mail : obedbida@gmail.com

\section{PENDAHULUAN}

Kajian tentang desentralisasi dan kesenjangan pendidikan dalam konteks negara kepulauan muncul karena sistem pendidikan yang selama ini dikelola dalam iklim birokratis sentralistik, dianggap sebagai masalah terhadap proses terjadinya kesenjangan dan keterpurukan mutu pendidikan di Indonesia. Desentralisasi menjadi sebuah paradigma antitesis terhadap kebijakan pemerintah yang sentralistik dari pemerintahan pusat yang hegemoni (Gramsci, 1999). Perubahan sistem politik yang dilakukan oleh bangsa Indonesia dari sentralisasi ke desentralisasi, menjadi langkah strategis terhadap perubahan sistem pengelolaan pendidikan yang lebih efektif dan efisien dengan lahirnya UndangUndang Otonomi Daerah No. 22 Tahun 1999, diperbaharui menjadi Undang-Undang No 32 Tahun 2004 dan Undang-Undang No. 23 Tahun 2014.

Hutagalung, (2004) bahwa perubahan sistem politik dari sentralistik ke desentralisasi, ternyata tidak serta-merta menjadi solusi dan obat mujarab terhadap pemerataan pembangunan di masyarakat. Dalam paradigma tertentu, kebijakan desentralisasi dapat dilihat secara kritis terhadap masalah kebijakan pemerintah daerah yang hegemoni terhadap pengelolaan sistem pendidikan karena dominasi elit politik lokal dalam proses kebijakan pendidikan. Hal ini beralasan, karena sistem birokrasi selalu menempatkan "kekuasaan" sebagai faktor yang paling menentukan dalam proses pengambilan keputusan (Parson, 2014). Disparitas pendidikan di masyarakat dapat dikategorikan dalam tiga hal yakni 1) disparitas struktural yang disebabkan karena kebijakan, 2) disparitas kultural dikarenakan budaya, 3) disparitas spasial karena perbedaan geografis (Effendy, 2016). Disparitas pendidikan merupakan masalah sosial yang tidak ada habisnya untuk diperdebatkan sebagai masalah publik (negara) dan senantiasa dihubungkan dengan permasalahan sosial budaya, ekonomi dan geografis masyarakat (Dorius 2013; Walter 2001; Montt 2011 \& Lewis 2007).

Perkembangan kebijakan desentralisasi pendidikan selama kurang lebih 18 tahun, ternyata sering kali mengalami banyak hambatan dan berpotensi mengganggu efisiensi, efektivitas dan profesionalisme pengelolaan pendidikan (Balitbang Kemendikbud, 2011). Para ilmuwan politik menemukan bahwa pada kasus tertentu, justru elit lokal dapat mengambil keuntungan dari kebijakan desentralisasi sebagaimana hasil penelitian desentralisasi yang dilakukan di India bahwa kebijakan desentralisasi tidak dapat berjalan efektif karena dominasi elit lokal dalam proses politik sehingga pemerintah daerah rawan terhadap fenomena elite capture di mana kepentingan elit lebih mendominasi proses politik (Malley, 2003; Bardhan \& Mookherjee, 2005). Kebijakan pendidikan di Indonesia belum sepenuhnya dapat berfungsi secara optimal sebagai perangkat yang efektif untuk mencapai tujuan pendidikan nasional, dikarenakan 
berbagai kebijakan pendidikan yang ditetapkan sering kali memiliki arah yang tidak jelas, saling silang dan tidak konsisten (Wibowo, 2015).

Secara teoritis, kebijakan desentralisasi dibidang pendidikan merupakan pilihan dalam membuat keputusan dan tahapannya dalam mempertimbangkan berbagai faktor lingkungan kebijakan itu sendiri. Oleh karena itu, penerapan kebijakan pendidikan dalam tata pemerintahan daerah seharusnya dapat difungsikan sebagai kondisi yang memberi kehidupan bermakna pada pendidikan nasional dalam dua hal yakni 1) kebijakan pendidikan dapat dimanfaatkan sebagai momentum pintu masuk untuk mendukung keberhasilan desentralisasi. 2) desentralisasi menjadi titik awal terjadinya reformasi pendidikan nasional untuk menjadi kekuatan vital dalam memutuskan keterbelakangan yang berkaitan dengan rendahnya tingkat pendidikan bangsa dan negara (Surakhmad, 2009). Dinamika kebijakan pendidikan melalui peningkatan akses dan kualitas pendidikan berdasarkan prinsip persamaan dan perbedaan masih menghadapi jalan terjal yang tidak ada habisnya untuk diperdebatkan. Nguyen (2011) menjelaskan bahwa kebijakan pendidikan seakan tidak sensitif terhadap masyarakat yang memiliki kondisi sosial budaya, ekonomi dan geografis masyarakat di daerah kepulauan sehingga sulit bagi mereka untuk tetap bersekolah. Permasalahan tersebut sejalan dengan kondisi pendidikan Indonesia saat ini yang masih mengalami problematika yang sangat kompleks dan menuju kondisi gawat darurat ${ }^{1}$.

\footnotetext{
1 Anies R. Baswedan. 2016. Mantan Menteri
} Pendidikan dan Kebudayaan yang
Secara empirik kondisi pendidikan Indonesia dilihat dari pemetaan the learning curve- person (pemetaan akses dan mutu pendidikan) berada di peringkat 40 dari 40 negara dan pemetaan PISA (Program for International Student Assessment) atau capaian kinerja pendidikan (Kemendikbud RI, 2016).

Provinsi Sulawesi Tenggara merupakan salah satu wilayah Indonesia bagian timur dengan kondisi geografis kepulauan dan termasuk provinsi yang memiliki tingkat kesenjangan pendidikan cukup tinggi dilihat dari jumlah anak putus sekolah pada berikut.

disampaikan pada silaturahmi dengan kepala dinas pendidikan provinsi/kabupaten/kota se-Indonesia. 
Tabel 1. Peringkat Tertinggi dan Terendah Anak Putus Sekolah di Indonesia

\begin{tabular}{|c|c|c|c|c|}
\hline No & $\begin{array}{l}\text { Tertinggi } \\
\text { Provinsi }\end{array}$ & $(\%)$ & $\begin{array}{c}\text { Terendah } \\
\text { Provinsi } \\
\end{array}$ & $(\%)$ \\
\hline 1 & Papua & 0,59 & Bali & 0,05 \\
\hline 2 & Papua Barat & 0,38 & Yogyakarta & 0,06 \\
\hline 3 & Maluku Utara & 0,32 & Jawa Timur & 0,06 \\
\hline 4 & Sulawesi Tenggara & 0,30 & Jawa Tengah & 0,08 \\
\hline 5 & Sulawesi Barat & 0,27 & Jawa Barat & 0,10 \\
\hline
\end{tabular}

Pendidikan Dasar Rata-Rata Nasional $(0,15)$

Sumber data : Kemendikbud (2016).

Berdasarkan peringkat anak putus sekolah pada tabel di atas dapat dijelaskan bahwa Provinsi Sulawesi Tenggara termasuk salah satu daerah yang tergolong memiliki tingkat anak putus sekolah tertinggi di Indonesia, khususnya pada tingkat pendidikan dasar sebesar $(0,30)$ persen dan berada di atas rata-rata standar nasional sebesar $(0,15)$ persen. Secara geografis Sulawesi Tenggara merupakan daerah kepulauan dan dihadapkan dengan kondisi infrastruktur pendidikan dasar yang terbatas ${ }^{2}$. Kondisi tersebut, memberi gambaran bahwa disparitas pendidikan tidak hanya dihadapkan oleh persoalan kondisi sosial budaya, ekonomi dan geografis, melainkan juga di determinan oleh proses kontestasi elit struktural dan elit politik yang syarat kepentingan di dalam merumuskan proses kebijakan pendidikan.

Kebijakan pendidikan merupakan produk politik, ikut mewarnai proses kebijakan yang dihasilkan dan menjadi persoalan ketika warna politik menjadi tidak

\footnotetext{
2 Provinsi Sulawesi Tenggara memiliki kondisi geografis wilayah daratan dan kepulauan terpencil dengan jumlah pulau sebanyak 552 pulau dan 2.247 desa/kelurahan. Sedangkan jumlah desa yang belum memiliki sekolah dasar terdiri dari 293 desa/kelurahan di wilayah daratan dan 142 desa/kelurahan di wilayah kepulauan (BPS Sultra, 2014).
}

proporsional yang kemudian didominasi oleh kepentingan tertentu. Sebagai produk politik, tentu syarat akan kepentingan masyarakat yang senantiasa menciptakan equality dan equity serta mengandung nilai moralitas sehingga dapat menghasilkan kebijakan pendidikan yang optimal. Analisis kebijakan pendidikan menjadi penting dilakukan untuk memberi masukan dan kritik terhadap konten dan proses kebijakan, untuk membongkar masalah pendidikan yang terpinggirkan bahwa dampak kumulatif analisis tersebut dapat memperkuat gagasan bahwa kebijakan publik hanya untuk para elit (Morgan, Rein \& Goodin, 2015).

Kebijakan publik merupakan ilmu multidisipliner yang melibatkan banyak disiplin ilmu seperti ilmu politik, sosial, ekonomi, dan psikologi. Studi kebijakan publik berkembang pada awal 1970-an terutama melalui tulisan Laswell \& Kaplan dalam (Howlett \& Ramesh, 1995). Istilah kebijakan secara luas dipergunakan atau dalam kaitannya dengan tindakan atau kebijakan-kebijakan pemerintah yang acap kali diberikan dengan makna tindakan politik. Wahab (1991) mengatakan bahwa kebijakan merupakan suatu tindakan yang mengarah pada tujuan yang diusulkan oleh seseorang, kelompok atau pemerintah, dalam lingkungan 
tertentu sehubungan dengan adanya hambatan-hambatan dan peluang untuk mewujudkan tujuan dan sasaran yang diinginkan.

Parsons (2014) mengatakan bahwa kebijakan publik tidak hanya menitikberatkan pada "publik dan problem-problemnya" tetapi juga membahas soal bagaimana isu-isu publik tersebut di konstruksi dan didefinisikan, kemudian diletakkan dalam agenda kebijakan dan politik. Kebijakan publik dalam pandangan Dye (2000) menjelaskan bahwa apapun yang dilakukan atau tidak dilakukan oleh pemerintah, pemerintah wajib bertanggung jawab terhadap apa yang terjadi di masyarakat baik menyangkut konflik yang diorganisir maupun masalah lain yang berupa pendistribusian sumber daya di masyarakat. Menurut Keban (2016) bahwa public policy dapat dilihat sebagai konsep filosofi, produk, dan proses sebagai suatu kerangka kerja yang tidak terlepas dari proses politik, tawar menawar dan negosiasi untuk merumuskan berbagai isu-isu publik dan metode implementasinya di masyarakat. Studi tentang desain kebijakan muncul sebagai tanggapan terhadap studi implementasi yang menganggap sistem birokrasi bertanggung jawab atas kegagalan kebijakan. Teori desain kebijakan berpendapat bahwa para sarjana harus melihat lebih holistik tentang sebab akibat mengapa kebijakan berhasil atau gagal karena proses perumusan kebijakan awal dan desain kebijakan itu sendiri, secara signifikan berkontribusi pada hasil kebijakan (Fischer, Miller \& Sidney, 2015).

Sementara Dunn (1994) mengatakan kebijakan publik biasanya diarahkan untuk menjawab atau memecahkan masalah-masalah kebijakan. Studi tentang desain kebijakan muncul sebagai tanggapan terhadap studi implementasi yang menganggap sistem birokrasi bertanggung jawab atas kegagalan kebijakan. Teori desain kebijakan berpendapat bahwa para sarjana harus melihat lebih jauh sebab akibat untuk memahami mengapa kebijakan berhasil atau gagal karena proses perumusan kebijakan awal dan desain kebijakan itu sendiri, secara signifikan berkontribusi pada hasil kebijakan (Fischer, Miller \& Sidney, 2015). Sedangkan asumsi rasionalitas keterbatasan dari Simon (1985) mengemukakan bahwa terbatasnya pengetahuan kita tentang dunia sosial, menyebabkan kebijakan fokus pada sebagian aspek dari masalah dengan mengorbankan aspek lain.

Perubahan kebijakan dalam pendidikan tentu tidak terlepas dari proses politik yang sangat kompleks karena dominasi kekuasaan yang syarat akan kepentingan penguasa. Kebijakan pendidikan di Indonesia "salah urus" atau krisis pendidikan dikarenakan kepemimpinan orde baru dan reformasi pendidikan terkooptasi oleh kepentingan politik, baik dari para politisi, pemerintah maupun ahli politik (Gunawan, 2010). Hasil penelitian yang dilakukan di 20 negara menunjukkan bahwa kemampuan partai politik sepenuhnya mengontrol pemerintah di dalam mempengaruhi pembuatan keputusan kebijakan pemerintah (Budge \& Keman, 1990). Kebijakan pendidikan merupakan produk politik pemerintah dalam mewujudkan pemerataan pelayanan pendidikan yang berkeadilan sosial. Dalam prosesnya, proses kebijakan pendidikan lebih menitikberatkan pada pendekatan politik, syarat kepentingan dan tidak demokratis sehingga terkesan sentralistis dengan tidak berdasarkan aspirasi masyarakat (Rohman, 2009). 
Kebijakan pendidikan merupakan bagian dari kebijakan publik karena berkaitan dengan bagaimana memposisikan pendidikan dalam konteks sektor publik yang harus dikelola secara serius dan besarnya tingkat urgensi bagi pemerintah dalam menetapkan prioritas program pembangunan (Bakrey, 2010: 12). Kebijakan pendidikan merupakan agenda pemerintah yang memusatkan perhatian pada hasil kebijakan dan implikasinya terhadap kesejahteraan sosial dan ekonomi masyarakat, akan tetapi sering kali pemahaman bagaimana kebijakan pendidikan terbentuk dan bagaimana dampaknya terhadap pendidikan di masyarakat, menjadi tantangan bagi kepemimpinan dalam dunia pendidikan (Bell dan Stevenson, 2005).

Desentralisasi bukanlah konsep yang mudah untuk didefinisikan karena konsep ini memiliki berbagai bentuk dan dimensi dalam praktiknya sebagaimana Cheema \& Rondinelli (1988) bahwa kebijakan desentralisasi sebagai transfer tanggung jawab terhadap perencanaan, manajemen dan alokasi sumber daya dari pemerintah pusat dan agennya kepada unit yang berada di bawahnya atau otoritas regional fungsional dalam wilayah yang luas. Bahkan desentralisasi diharapkan dapat mewujudkan good governance yang dalam praktiknya dapat menerapkan nilai-nilai efektivitas, efisiensi, transparansi dan partisipasi dalam penyelenggaraan kebijakan publik (Dwiyanto, 2005).

\section{Secara}

konseptual desentralisasi dapat dijelaskan dalam tiga model yakni 1) Deconcentration adalah model pengalihan tanggung jawab pengelolaan pendidikan dari pemerintah pusat kepada pemerintahan yang lebih rendah sehingga lembaga di pemerintah pusat masing-masing memegang kendali pelaksanaan pendidikan secara penuh. Model ini sering kali dilaksanakan dengan membentuk lembaga setingkat direktorat di daerah yang dapat melaksanakan tanggung jawab pemerintah pusat. 2) Delegation adalah model desentralisasi di mana pemerintah pusat meminjamkan kekuasaannya kepada pemerintah daerah atau kepada organisasi semi otonom. Kekuasaan pemerintah pusat tidak diberikan melainkan dipinjamkan dan dapat ditarik kembali apabila pemerintah pusat memandang perlu untuk dikembalikan kepada pemerintah pusat. 3) Devolution adalah pelimpahan wewenang pemerintah pusat kepada pemerintah daerah secara permanen dengan cara menyerahkan seluruh pelaksanaan pendidikan meliputi pembiayaan, administrasi serta pengelolaan yang lebih luas (Dwiningrum, 2011).

Berdasarkan ketiga tingkatan model tersebut, maka tingkat kewenangan yang dilimpahkan akan berkonsekuensi terhadap implementasinya di lapangan dalam artian bahwa semakin besar kewenangan yang diterima pemerintah pusat maka semakin besar sumber daya yang harus dikeluarkan untuk melaksanakan kewenangan tersebut. Dwiyanto, (2005) menjelaskan beberapa alasan perlunya dilakukan desentralisasi oleh pemerintah pusat antara lain; (1) aspek politik, desentralisasi dimaksudkan untuk kepentingan daerah maupun untuk kepentingan politik dan kebijakan nasional melalui pembangunan proses demokrasi di lapisan bawah, (2) aspek manajemen, desentralisasi dapat meningkatkan efektivitas, efisiensi dan akuntabilitas publik, (3) aspek kultural, 
desentralisasi dimaksudkan untuk memperhatikan kekhususan, keistimewaan suatu daerah seperti geografis, kondisi penduduk, perekonomian dan kebudayaan. Perubahan sistem politik dari sentralistis ke desentralisasi, secara mendasar memberikan dampak terhadap pengelolaan pendidikan di mana kontrol pemerintah pusat terhadap kebijakan pemerintah daerah dalam bidang pendidikan semakin kecil walaupun secara kepemimpinan dapat memberikan kewenangan secara luas bagi pemerintah daerah untuk mengatur pengelolaan pendidikan sesuai dengan potensi daerah masingmasing (Fuhrman, 1987). Tingginya partisipasi politik terhadap adanya kebijakan desentralisasi tidak sertamerta memberikan dampak terhadap perubahan positif pengelolaan pendidikan di masyarakat (Mukundan and Bray, 2004).

Paqueot \& Lammert (2000) menjelaskan bahwa desentralisasi pendidikan memberikan kesempatan kepada pemerintah daerah untuk mengambil keputusan terbaik tentang penyelenggaraan pendidikan di daerah berdasarkan potensi daerah. Oleh karena itu, desentralisasi pendidikan di samping diakui sebagai kebijakan politis yang berkaitan dengan pendidikan, juga merupakan kebijakan yang berkaitan dengan kemampuan pembiayaan dan partisipasi masyarakat. Analisis kebijakan pendidikan menjadi penting dilakukan untuk memberi masukan dan kritik terhadap konten dan proses kebijakan, untuk membongkar masalah pendidikan yang terpinggirkan bahwa dampak kumulatif analisis tersebut dapat memperkuat gagasan bahwa kebijakan publik hanya untuk para elit (Morgan, Rein \& Goodin, 2015).
Jane C Millar Wods dalam Putra (2015) menjelaskan desentralisasi dalam reformasi pendidikan memiliki tujuan untuk meningkatkan kualitas, efektivitas, dan efisiensi penyediaan pelayanan pendidikan dalam sebuah negara. Meski demikian kebijakan desentralisasi pendidikan juga memberi tantangan yang bersifat paradoks bagi negara, di satu sisi negara dituntut untuk tetap mengontrol kebijakan pendidikan dan kualitas pendidikan melalui berbagai standar kualitas secara nasional, di sisi yang lain kontrol negara dengan adanya kebijakan desentralisasi pendidikan semakin kecil. Salah satu persoalan besar dalam bidang pendidikan saat ini adalah disparitas pendidikan antar daerah dan sekolah yang erat kaitannya dengan masalah peluang dan kesempatan yang sama bagi masyarakat terhadap akses pendidikan berkualitas. Berdasarkan hasil kajian studi desentralisasi tentang disparitas pendidikan belum sepenuhnya dapat berjalan optimal dikarenakan dominasi elit lokal dalam proses kebijakan pendidikan di daerah yang masih menempatkan kekuasaan sebagai faktor yang paling dominan dalam proses pengambilan keputusan (Bardhan \& Mookherjee, 2005; Malley, 2003). Sementara hasil penelitian yang dilakukan ilmuwan politik lainnya bahwa desentralisasi tidak serta-merta mampu mendorong masyarakat yang partisipatif melainkan juga mengulas bagaimana kegagalan praktik desentralisasi di Meksiko dan menyimpulkan bahwa salah satu penyebab kegagalan desentralisasi adalah lemahnya partisipasi masyarakat (Grinde, (2007).

Munculnya disparitas pendidikan di masyarakat, tidak terlepas dari permasalahan kebijakan 
pendidikan yang bias dan tidak meratanya akses sumber daya pendidikan di masyarakat (Sukmana, 2005). Oleh karena itu, keberhasilan pembangunan tidak cukup hanya dilihat dengan menggunakan indikator ekonomi melainkan perlu didukung oleh aspek-aspek sosial dan budaya. Secara teoritis, kesenjangan pendidikan sekurang-kurangnya terdapat dua faktor utama yang menghambat dan menyebabkan terjadinya kesenjangan di masyarakat: 1) faktor internal yaitu faktor yang berasal dari dalam diri seseorang yang terdiri dari: rendahnya kualitas sumber daya manusia karena tingkat pendidikan yang terbatas, tingkat kesehatan rendah dan adanya hambatan budaya kemiskinan. Kesenjangan pendidikan dapat muncul sebagai akibat dari nilai-nilai kebudayaan yang dianut oleh sekelompok masyarakat yang cenderung apatis, menyerah pada nasib, tidak memiliki daya juang dan tidak mempunyai orientasi kehidupan masa depan. 2) faktor eksternal yaitu berasal dari luar kemampuan seseorang dan dapat terjadi karena himpitan birokrasi melalui peraturan-peraturan (kebijakan) yang dapat membatasi atau memperkecil akses seseorang untuk memanfaatkan kesempatan dan peluang yang tersedia. Dengan kata lain bahwa kesenjangan sosial bukan terjadi karena seseorang malas bekerja atau tidak mempunyai kemampuan sebagai akibat keterbatasan atau rendahnya kualitas sumber daya manusia, tetapi karena ada hambatan-hambatan struktural yang disebabkan oleh birokrasi atau kebijakan pemerintah (Lewis, (1983).

Bremen (1997) menjelaskan lebih lanjut bahwa kesenjangan tidak semata-mata disebabkan faktor internal dan kebudayaan, tetapi lebih disebabkan oleh adanya hambatan struktural yang dapat membatasi dan tidak memberikan peluang bagi masyarakat untuk memanfaatkan kesempatan-kesempatan yang ada sehingga bagi yang miskin sering kali "jalan ke atas sering kali dirintangi", sedangkan bagi yang kaya, "jalan menuju ke bawah terlalu mudah dilalui". Sementara disparitas regional di negara-negara berkembang cenderung disebabkan oleh kebijakan pemerintah dan lembaga-lembaga feodal lainnya yang bersikap tidak adil di dalam proses pembangunan khususnya masyarakat yang berada di daerah pinggiran. Struktur kekuasaan bahkan cenderung melakukan eksploitasi sumber daya daerah-daerah pinggiran untuk menunjang pembangunan pada daerah-daerah pusat pertumbuhan di perkotaan. Perbedaan perkembangan wilayah yang tidak seimbang akan memperlihatkan terjadinya disparitas yang semakin besar. Hal ini dapat terjadi apabila kemajuan perkembangan terjadi di daerah yang perkembangannya masih rendah, maka disparitas antar daerah akan semakin kecil, tetapi jika kemajuan perkembangan terjadi pada daerah yang sudah tinggi tingkat pertumbuhannya maka dalam sistem wilayah tersebut akan terjadi disparitas perkembangan yang semakin besar (Nurzaman, 2002).

\section{METODE PENELITIAN}

Penelitian ini menggunakan metode pendekatan deskriptif kualitatif interaktif dengan teknik pengumpulan data melalui observasi, studi dokumen dan wawancara mendalam. Proses observasi dilakukan dengan melakukan pengamatan langsung terhadap kondisi sosial pendidikan masyarakat dan melakukan pemetaan kondisi infrastruktur dasar pendidikan 
antara sekolah dan wilayah di daerah Kabupaten Buton dan Buton Selatan, untuk dijadikan suatu gambaran awal kondisi realitas pendidikan di daerah. Proses wawancara mendalam dilakukan dengan berbagai stakeholder pemerintah daerah di Kabupaten Buton dan Buton Selatan yang terdiri dari Bupati, DPRD (Komisi Pendidikan), Bappeda (Sekda dan Staf), Dinas Pendidikan, Dewan Pendidikan, Praktisi Pendidikan, Kepala Sekolah dan Guru. Pemilihan informan dilakukan dengan purposive sampling yaitu mereka yang mengetahui atau terlibat langsung maupun tidak langsung dalam proses kebijakan pendidikan di daerah. Studi dokumen merupakan proses penelusuran sumber data dari dinas terkait yang dapat dijadikan sumber informasi untuk mendukung data hasil observasi dan wawancara yang telah peneliti kumpulkan dalam penelitian kebijakan desentralisasi dan disparitas pendidikan dasar di daerah kepulauan Kabupaten Buton dan Buton Selatan. Selanjutnya untuk menjamin tingkat keakuratan data hasil penelitian tersebut, dilakukan proses triangulasi hasil sumber data penelitian untuk mengecek data yang satu dengan data yang lainnya melalui triangulasi sumber, metode dan teori (Moleong, 2007).

\section{HASIL DAN DISKUSI/ANALISIS}

Perubahan sistem politik Undang-Undang Otonomi Daerah No. 22 Tahun 1999 yang diperbaharui menjadi Undang-Undang No 32 Tahun 2004 dan direvisi menjadi Undang-Undang No. 23 Tahun 2014 membawa semangat baru dan angin segar bagi pemerintah daerah untuk mengambil tanggung jawab yang lebih besar dalam penyelenggaraan pendidikan di daerah. Kebijakan pendidikan di era otonomi daerah menjadi bagian dari komitmen politik pemerintah untuk mendekatkan pelayanan pendidikan melalui UU Nomor 25 Tahun 2004 tentang Sistem Perencanaan Pembangunan Nasional dan Peraturan Menteri Dalam Negeri Nomor 54 Tahun 2010. Hasil analisis penelitian ini menemukan bahwa proses kebijakan pendidikan di daerah ternyata tidak menciptakan keseimbangan dalam pemerataan pendidikan bahkan cenderung membuka ruang disparitas pendidikan di masyarakat.

Kebijakan desentralisasi

pendidikan di daerah tidak berjalan efektif karena dominasi elit lokal dalam proses politik sehingga pemerintah daerah riskan terhadap fenomena "elite capture" di mana kepentingan politik lebih mendominasi dibandingkan kondisi realitas suatu daerah. Hal ini dapat terlihat dari dinamika proses kebijakan pendidikan pada pemerintahan daerah yang terbagi dalam dua arus utama yakni 1) proses kontestasi elit struktural dalam birokrasi dan 2) proses kontestasi elit politik (eksekutif dan legislatif). Kedua arus utama tersebut, kerap menjadi patologi dalam birokrasi pendidikan dan menghambat ruang gerak partisipasi masyarakat terhadap peningkatan akses dan kualitas pendidikan di masyarakat. Bahkan kontestasi elit struktural dan elit politik berpotensi mengganggu efektivitas dan profesionalisme pengelolaan pendidikan serta membuka ruang disparitas pendidikan di masyarakat.

\section{Kontestasi Elit Struktural dalam Birokrasi Pendidikan \\ Dinamika proses kebijakan pendidikan dalam konteks otonomi daerah, memperlihatkan komitmen pemerintah untuk menata dan mewujudkan tata kelola pemerintahan daerah yang}


demokratis dan akuntabel, masih terbatas pada konsep rencana strategis dan belum dapat diimplementasikan sebagaimana konsep undang-undang otonomi daerah. Melalui mekanisme perencanaan pembangunan kolaboratif dengan pendekatan teknokratis, demokratis dan partisipatif. Proses kebijakan pendidikan di daerah melalui suatu rangkaian proses dan berbagai tahapan yang sangat kompleks mulai dari tahapan proses teknis kebijakan, pelaksanaan program maupun kebijakan yang dihasilkan. Dalam prosesnya dinas pendidikan sebagai Satuan Kerja Perangkat Daerah (SKPD) memiliki tugas dan fungsi untuk melaksanakan urusan pemerintahan daerah di bidang pendidikan berdasarkan asas otonomi termasuk di dalamnya melakukan perumusan kebijakan teknis di bidang pendidikan.

\section{Perumusan}

program pembangunan bidang pendidikan di tingkat dinas pendidikan merupakan masalah yang paling mendasar dari keseluruhan sektor pembangunan yang diperlukan oleh pemerintah daerah dalam rangka meningkatkan akses dan kualitas sumber daya manusia di masyarakat. Pembangunan sektor pendidikan memiliki kompleksitas dan memerlukan perencanaan yang sangat detail, kritis, dan strategis. Dinas Pendidikan Kabupaten Buton dan Buton Selatan sebagai Satuan Kerja Perangkat Daerah menyusun suatu rencana strategis yang selanjutnya disebut Renstra (SKPD) yang kemudian dituangkan dalam Rencana Kerja (Renja) tahunan. Perumusan program kerja dinas pendidikan yang kemudian diusulkan kepada Badan Perencanaan Pembangunan Daerah (Bappeda) untuk dijadikan sebagai bagian dari kebijakan program pembangunan pemerintah daerah yang biasa di sebut Rencana Kerja Pembangunan Daerah (RKPD). Dalam menjalankan tugas dan fungsinya dinas pendidikan bertanggung jawab kepada bupati melalui Sekretaris Daerah (Sekda), oleh karena itu program kerja dinas pendidikan merupakan terjemahan dari Rencana Pembangunan Jangka Menengah Daerah (RPJMD).

Pembahasan program kerja dinas pendidikan bersama dengan Badan Perencanaan Pembangunan Daerah (Bappeda) merupakan tahapan awal dalam proses kontestasi kebijakan pendidikan di daerah. Menurut Sekretaris Daerah (Sekda) bahwa proses pembahasan program kerja bersama Bappeda bertujuan untuk melakukan sinkronisasi program dinas pendidikan dengan RPJMD agar tidak terjadi tumpang tindih antara program kerja dinas yang satu dengan lainnya. Sebelum pembahasan program kerja dinas pendidikan terlebih dahulu menyiapkan Rencana Kerja Anggaran (RKA) SKPD untuk diusulkan sebagai program kerja tahunan dan dipresentasikan di hadapan Bappeda untuk dapat dijadikan sebagai RKPD. Dalam desain awal pembahasan program kerja dinas pendidikan di daerah seharusnya dihadiri oleh Dinas Pendapatan Pengelolaan Keuangan dan Aset Daerah (DPPKAD) bersama anggota legislatif yang diundang. Kenyataannya bahwa pembahasan program kerja dinas pendidikan bersama Bappeda tidak dihadiri oleh DPPKAD dan anggota legislatif sehingga yang terjadi adalah saling adu program dan argumentasi antara dinas pendidikan dengan Bappeda menyangkut program kerja yang diusulkan oleh dinas pendidikan. Pembahasan program kerja antara dinas pendidikan dan 
Bappeda terkadang menjadi tidak berimbang karena dinas pendidikan ditempatkan sebagai posisi yang lemah, lebih banyak mengalah dan harus mengikuti desain program kerja Bappeda. Sehingga diskursus antara Diknas dan Bappeda cenderung mengarah pada negosiasi kepentingan antar sektor melalui lobi-lobi elit struktural untuk meloloskan program kerja dengan pertimbangan skala prioritas dan keterbatasan anggaran sebagaimana dijelaskan informan berikut.

"Forum diskusi pembahasan program kerja dinas pendidikan dengan Bappeda sebenarnya hanya buang-buang waktu saja pak, kita dibantai habis-habisan, forum ini hanya sekedar formalitas administratif karena pada saat pembahasan program kerja belum ada anggaran definitif dan setelah forum ini selesai program kerja yang telah dibahas bersama tidak dipakai lagi dan pada akhirnya kami harus menyusun RKA yang baru. Karena setelah ada alokasi anggaran, kami harus melakukan asistensi kembali ke Bappeda (Wawancara dengan staf diknas EG, 15 Desember 2017)".

Permasalahan tersebut, juga diiyakan oleh kepala dinas pendidikan Kabupaten Buton Selatan bahwa dalam perencanaan program kerja bidang pendidikan tahun anggaran 2018 kami mengalokasikan dana sebesar 30 miliar untuk meningkatkan akses dan kualitas pendidikan, akan tetapi setelah dilakukan finalisasi bersama anggota DPRD kami hanya diberi anggaran sebesar 10 miliar. Sehingga sulit bagi dinas pendidikan untuk meningkatkan akses dan kualitas pendidikan di Kabupaten Buton Selatan dan kalau melihat akses dan kualitas pendidikan di daerah Provinsi Sulawesi Tenggara, Kabupaten Buton Selatan termasuk salah satu daerah yang memiliki tingkat akses dan kualitas pendidikan paling rendah, oleh karena itu berkaitan dengan kebijakan yang menyangkut dengan pendidikan semuanya sangat ditentukan oleh penguasa atau pejabat politik dalam hal ini bupati sebagai kepala daerah.

Dinamika kontestasi elit struktural dalam birokrasi pemerintahan, dinas pendidikan senantiasa diposisikan di bawah kendali Bappeda sehingga desain kebijakan dan program yang dirancang oleh diknas selalu mentah dan tidak berjalan sesuai harapan dinas pendidikan. Oleh karena itu, idealnya dalam proses penyusunan kerja, keberadaan Bappeda mestinya sebagai fasilitator dan mengarahkan terkait dengan arah kebijakan politik pemerintah daerah, akan tetapi pada kenyataannya program kerja diknas hanya sebagai pelengkap. Dominasi Bappeda dalam setiap perencanaan pembangunan bidang pendidikan cenderung lebih mencerminkan program kerja Bappeda. Menariknya bahwa ketika kepala dinas pendidikan mencoba untuk merespons kebijakan dan program kerja yang diusulkan berbeda dengan yang disetujui oleh Bappeda, hal ini menjadi bumerang bagi setiap kepala dinas pendidikan, karena dianggap melawan dan tidak loyal terhadap pimpinan sehingga berdampak terhadap posisi dan jabatan sebagai kepala dinas. Sebagaimana yang terjadi di daerah Kabupaten Buton Selatan ketika terjadi promosi dan mutasi jabatan posisi kepala dinas pendidikan yang baru menjabat kurang lebih satu tahun langsung diganti oleh pejabat baru. Sementara dalam Undang-Undang ASN Tahun 2014 menegaskan bahwa posisi birokrasi pada sistem meritokrasi bertujuan untuk meminimalisir praktik politisasi birokrasi, justru 
bertolak belakang dengan kenyataan terjadi dalam birokrasi saat ini, di mana penghargaan profesionalisme birokrasi melalui UU ASN menegaskan bahwa pejabat birokrasi (eselon II) tidak dapat dipindahkan atau dimutasi sekurang-kurangnya dalam waktu dua tahun tanpa alasan yang jelas. Kontrol pejabat politik dalam era otonomi daerah terhadap pejabat birokrasi, tidak saja terjadi di level eselon II akan tetapi sampai pada jabatan kepala sekolah yang setara dengan eselon IV, semuanya di bawah kendali bupati sebagai pejabat politik. Penempatan pejabat birokrasi yang cenderung lebih menitikberatkan pada pertimbangan politik hanya akan dapat merusak birokrasi (Monsod, 2017).

Sejalan dengan pernyataan di atas maka dapat dijelaskan bahwa pembahasan program kerja bersama Badan Perencanaan Pembangunan Daerah sesungguhnya tidak mencerminkan program kerja dinas pendidikan secara utuh karena dalam forum proses pembahasaan program kerja tersebut lebih cenderung sebagai tempat untuk menyortir program kerja dinas pendidikan. Sehingga program kerja yang telah disusun oleh dinas pendidikan kerap tidak memberikan gambaran kondisi sosial budaya, ekonomi dan geografis pendidikan di daerah yang sebenarnya karena telah banyak mendapat respons dan perubahan dari elit struktural (Bappeda) tanpa melihat dan mempertimbangkan kondisi sosial ekonomi dan geografis masyarakat secara holistik sebagaimana yang telah dilakukan oleh dinas pendidikan. Ironisnya setelah forum diskusi dengan Bappeda, dinas pendidikan harus menyusun program kerja yang baru karena pada saat forum tersebut masih menggunakan pagu indikatif. Proses kontestasi kebijakan pendidikan tidak berhenti pada tingkat elit struktur birokrasi dalam pemerintahan daerah melainkan terus berlanjut ke tingkat elit politik antara pemerintah daerah selaku eksekutif dan elit politik (legislatif) sebagai representasi masyarakat di daerah.

\section{Kontestasi Elit Politik dalam Proses Kebijakan Pendidikan}

Kontestasi kebijakan di bidang pendidikan tidak berhenti pada pembahasan program kerja di tingkat Diknas dan Bappeda tetapi berlanjut pada tingkat elit politik yakni antara pemerintah daerah dan legislatif dengan dinamika dan tarik menarik kepentingan masing-masing. Berkaitan dengan ke tiga fungsi DPRD sebagai fungsi legislasi, fungsi anggaran dan fungsi pengawasan maka pemerintah daerah wajib untuk mempresentasikan Rencana Program Kerja Pemerintah Daerah (RKPD) kepada legislatif sehubungan dengan kebijakan program, anggaran dan sumber dana yang telah dimuat dalam RAPBD bidang pendidikan.

Sebelum proses pembahasan paripurna program kerja pemerintah daerah, terlebih dahulu terjadi komunikasi politik "belakang panggung" antara unsur pimpinan (eksekutif) dan unsur pimpinan legislatif (DPRD). Pada prinsipnya komunikasi politik sebelum pembahasan paripurna RAPBD bidang pendidikan dilakukan dengan maksud untuk mempermudah proses pembahasan paripurna program kerja RAPBD agar tidak banyak mendapatkan tanggapan negatif ketika pembahasan paripurna program kerja pemerintah daerah sehingga bisa langsung mendapatkan persetujuan dari pihak legislatif. Pada realitasnya bahwa proses komunikasi politik "belakang panggung" mengarah pada proses lobi-lobi 
politik dan tarik menarik kepentingan antara eksekutif dan legislatif. Proses komunikasi politik belakang panggung kemudian berubah menjadi arena pertarungan kepentingan antara eksekutif dan legislatif dengan pemetaan skala prioritas program kerja pemerintah daerah, dengan tetap memperhatikan kepentingan legislatif sebagai hasil pemenuhan reses anggota legislatif.

Sementara pada proses pembahasan paripurna program kerja bidang pendidikan yang telah dituangkan ke dalam RAPBD selama ini berjalan biasa-biasa saja dalam kondisi normal sesuai dengan mekanisme dan prosedur yang telah dijadwalkan. Perdebetan tentang kebijakan dan program kerja dalam pembahasan paripurna, hampir jarang terjadi karena telah didahului dengan komunikasi politik "belakang panggung" dan sekiranya terjadi perdebatan dalam proses pembahasan paripurna program kerja adalah bagian dari proses drama politik yang telah di desain antara eksekutif dan legislatif. Sehingga pada saat pembahasan paripurna tentang kebijakan dan program kerja pemerintah daerah tidak banyak mendapatkan respons negatif dari pihak legislatif melainkan sekedar memperjelas maksud dan tujuan dari kebijakan dan program kerja pemerintah daerah. Kalaupun dalam proses pembahasan paripurna kebijakan dan program kerja pemerintah daerah masih ada yang belum disepakati bersama dengan pihak legislatif (DPRD) maka akan dilanjutkan pasca pembahasan paripurna, melalui lobi-lobi elit politik untuk menuntaskan silang pendapat antara pemerintah daerah dan legislatif. Komunikasi politik "belakang panggung", jarang diungkap ke permukaan publik karena yang terlibat dalam komunikasi dan interaksi politik tersebut hanya unsur pimpinan dan proses komunikasi cenderung mengarah ke masalah kepentingan politik antara eksekutif dan legislatif. Hal ini sejalan dengan pernyataan anggota dewan dan kepala dinas bahwa berbicara tentang kebijakan pendidikan sesungguhnya sangat tergantung dari penentu kebijakan yakni Bupati dan unsur pimpinan di legislatif. Proses kontestasi di tingkat struktural birokrasi dan elit politik menunjukkan dominasi faktor politik dalam proses kebijakan dapat mengejawantahkan persoalan nilainilai sosial budaya, ekonomi dan geografis yang kemudian dapat memberikan dampak terhadap disparitas infrastruktur, akses dan kualitas pendidikan di masyarakat.

Proses kebijakan pendidikan pada prinsipnya tidak jauh berbeda dengan pola kebijakan pemerintahan sentralistik. Pola kebijakan desentralisasi sebagai bagian dari kebijakan politik yang berkembang di daerah pada realitasnya tidak berjalan efektif karena dominasi elit lokal di daerah sehingga pemerintah daerah rawan terhadap fenomena elite capture di mana kepentingan elit lebih mendominasi proses politik (Bardhan \& Mookherjee, 2005 ; Malley, 2003). Sebagaimana ilustrasi tahapan proses kontestasi aktor dalam proses kebijakan pendidikan di pemerintah daerah Kabupaten Buton dan Buton Selatan pada gambar berikut. 
Tahapan Proses Kebijakan Pendidikan

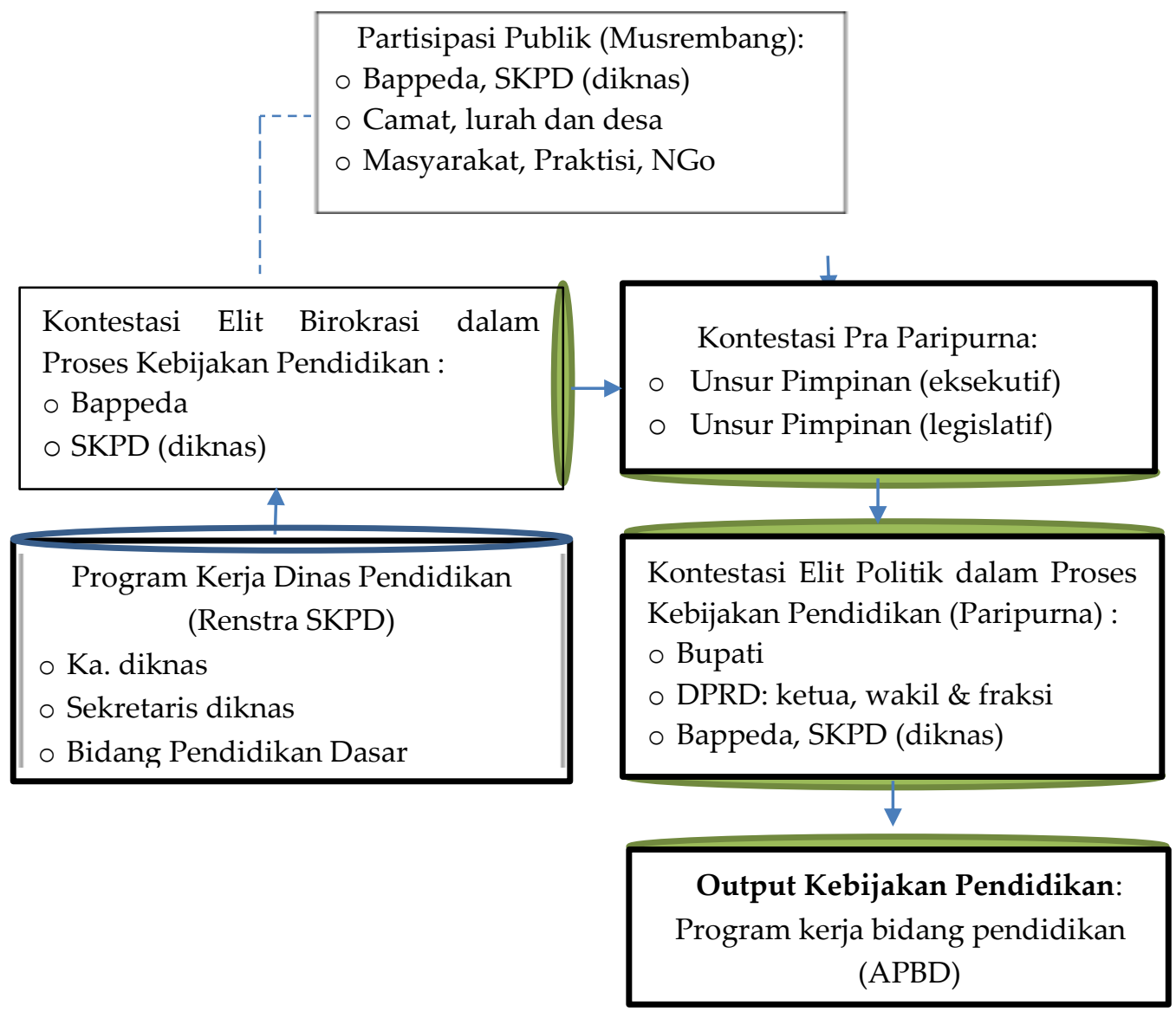

Sumber: Ilustrasi Penulis 2017

\begin{abstract}
Tahapan proses kebijakan bidang pendidikan di atas memperlihatkan proses kebijakan tidak hanya berlaku di ruang hampa melainkan juga melibatkan aktoraktor politik yang memiliki kepentingan yang sangat kompleks. Dominasi elit dalam proses kebijakan memperlihatkan lemahnya kapasitas pemerintah daerah dalam mengelola pendidikan di daerah. Kontrol elit politik (DPRD) terhadap kebijakan pendidikan sangat besar, hal ini terjadi ketika proses pra paripurna
\end{abstract}

pembahasan kebijakan pendidikan atas inisiatif legislatif yang kemudian dapat mempengaruhi pemerintah dalam mendesain kebijakan pendidikan di daerah. Hal ini dapat ditunjukkan dengan komitmen politik pemerintah daerah dan legislatif terhadap persentase anggaran urusan pendidikan dalam Anggaran Pendapatan dan Belanja Daerah (APBD) sebagaimana alokasi anggaran pendidikan daerah Kabupaten Buton dan Buton Selatan pada tabel berikut. 
Tabel. Anggaran Pendidikan Kabupaten Buton dan Buton Selatan dalam APBD (Miliar) Tahun 2016

\begin{tabular}{lcccc}
\hline \multirow{2}{*}{ Kabupaten } & Dana & \multicolumn{2}{c}{ Urusan Pendidikan } & Total \\
\cline { 3 - 4 } & APBD & Dana Daerah & Transfer Pusat & APBD \\
\hline Buton & 592.6 & 74.1 & 127.9 & 794.6 \\
Buton Selatan & 419.2 & 54.5 & 58.7 & 532.4 \\
\hline
\end{tabular}

Sumber Data: diknas Buton \& Busel 2016 (diolah).

Berdasarkan tabel besaran
alokasi anggaran pendidikan
pemerintah daerah Kabupaten Buton
dan Kabupaten Buton Selatan dapat
di jelaskan bahwa alokasi anggaran
pendidikan sesungguhnya belum
memenuhi ketentuan Undang-
Undang Sistem pendidikan Nasional Nomor 20 tahun 2003 menjelaskan bahwa alokasi anggaran pendidikan minimal 20 persen dari dana APBD. Hal ini terlihat dari jumlah alokasi anggaran pendidikan Kabupaten Buton dan Buton Selatan tidak mencapai sebesar 20 persen di luar transfer pusat yang bersumber dari Dana Alokasi Umum (DAU) dan Dana Alokasi Khusus (DAK). Anggaran pendidikan Kabupaten Buton di luar transfer daerah hanya sebesar 9 persen dari anggaran APBD dan 16 persen bersumber dari anggaran transfer pemerintah pusat. Sementara besaran anggaran pendidikan di Kabupaten Buton Selatan juga memperlihatkan masalah yang serupa yakni sebesar 13 persen dari dana APBD dan 14 persen bersumber dari dana transfer pemerintah pusat melalui dana DAU dan DAK.

Komitmen pemerintah daerah dan legislatif Kabupaten Buton dan Buton Selatan terhadap pemenuhan anggaran pendidikan sejauh ini belum memenuhi ketentuan dalam Undang-Undang Pendidikan Nomor 20 Tahun 2003 sebesar 20 persen.
Hal ini sejalan dengan penyampaian Menteri Pendidikan dan Kebudayaan bahwa masih banyak pemerintah daerah yang belum mengalokasikan anggaran pendidikan. Hal ini memperlihatkan bahwa dominasi elit politik dalam proses kebijakan pendidikan masih sangat dipengaruhi oleh kepentingan politik dibandingkan dengan melihat kepentingan sosial ekonomi dan geografis masyarakat. Dinamika kontestasi kebijakan pendidikan, tidak hanya terjadi di tingkat elit politik tetapi juga terjadi di tingkat struktur birokrasi pemerintah daerah. Sebagaimana dijelaskan Parson (2014) bahwa kemampuan elit politik dalam mengontrol pemerintah dalam mempengaruhi pembuatan keputusan memperlihatkan dominasi elit sebagai salah satu faktor penentu dalam proses desain kebijakan pendidikan di daerah.

Jane C Millar Wods dalam Putra (2015) menjelaskan desentralisasi dalam reformasi pendidikan memiliki tujuan untuk meningkatkan kualitas, efektivitas, dan efisiensi pelayanan pendidikan dalam sebuah negara. Meski demikian kebijakan desentralisasi pendidikan juga memberi tantangan yang bersifat paradoks terhadap pemerintah daerah (negara) karena di satu sisi negara dituntut untuk tetap mengontrol kebijakan 
pendidikan dan kualitas pendidikan melalui berbagai standar kualitas secara nasional, sementara di sisi lain yang lain kontrol negara dengan adanya kebijakan desentralisasi pendidikan semakin kecil. Sementara para ilmuwan politik menemukan bahwa pada kasus tertentu elit lokal justru mengambil keuntungan dari kebijakan desentralisasi sebagaimana Bardhan dan Mookherjee (2005) juga Malley (2003) menjelaskan bahwa ternyata kebijakan desentralisasi tidak dapat berjalan efektif karena dominasi elit lokal dalam proses politik di daerah, sehingga pemerintah daerah rawan terhadap fenomena "elite capture" di mana kepentingan elit lebih mendominasi dalam proses politik kebijakan pendidikan.

Berdasarkan hasil temuan tersebut dapat disimpulkan bahwa proses kebijakan pendidikan di era desentralistik cenderung di dominasi oleh sistem politik yang syarat kepentingan, dibanding memperhitungkan kondisi nilai-nilai sosial budaya, ekonomi dan geografis masyarakat. Dominasi elit politik di berbagai tahapan struktur birokrasi dalam proses kebijakan memperlihatkan kontrol elit politik terhadap kebijakan pemerintah (negara) turut mempengaruhi terjadinya disparitas pendidikan terhadap akses dan kualitas pendidikan daerah sentra maupun daerah kepulauan (pinggiran). Proses tahapan kebijakan pendidikan pada pemerintahan daerah cenderung didominasi oleh elit birokrasi dan elit politik yang saling sandera untuk kepentingan masing-masing aktor, baik di tingkat struktur birokrasi maupun di tingkat elit politik. Politik saling sandera menjadi hal biasa terjadi karena secara konstitusi dan secara kelembagaan, struktur birokrasi pemerintahan di tingkat pusat maupun di tingkat daerah dalam menjalankan tugas dan fungsinya, senantiasa di bawah kontrol dan kendali oleh elit politik. Berdasarkan hasil analisis kebijakan pendidikan di daerah Kabupaten Buton dan Buton Selatan, peneliti berpendapat bahwa proses kebijakan pendidikan di daerah cenderung mengarah pada arena pertarungan kepentingan antara elit struktural dan elit politik dan tidak menunjukkan bagian dari realitas analisis kondisi sosial budaya, ekonomi dan geografis suatu daerah sehingga yang terjadi bahwa proses kebijakan pendidikan tidak mencerminkan prinsip Justice as Fairness yakni memberikan kesempatan yang sama berdasarkan prinsip perbedaan kehidupan sosial, ekonomi dan geografis masyarakat (Rawls, 2011).

\section{Kekuasaan Politik dalam Proses Kebijakan Pendidikan}

$\begin{array}{lll}\text { Melihat } & \text { skema alur dan } \\ \text { mekanisme proses kebijakan } \\ \text { pendidikan pada pemerintahan }\end{array}$ daerah di atas, dapat dijelaskan bahwa dominasi elit dalam setiap pengambilan keputusan tidak terlepas dari determinasi elit struktur birokrasi maupun elit politik. Situasi tersebut, tentunya tidak terlepas dari keberadaan kepala daerah sebagai pejabat politik sehingga sulit bagi pemerintah daerah untuk keluar dari bayang-bayang kepentingan politik di atas kepentingan pemerintah (negara). Hal ini sejalan dengan pernyataan kepala dinas pendidikan sebelumnya bahwa berkaitan dengan kebijakan pendidikan di daerah, semuanya di bawah kontrol kepala daerah sebagai penentu dalam pengambilan keputusan sehingga program kerja yang telah dirumuskan di tingkat diknas dapat dimentahkan oleh keputusan politik seorang 
bupati. Pengalaman yang terjadi di daerah Kabupaten Buton Selatan sejak Bupati Agus Faisal menjabat dari tahun 2017-2018 telah terjadi tiga kali pergantian kepala dinas pendidikan karena kebijakan dan program diknas terkadang berbenturan dengan arahan Bappeda dalam agenda setting kebijakan dan program sebelum akhirnya beliau di tangkap KPK dalam kasus Operasi Tangkap Tangan (OTT) terkait proyek daerah bersama 9 orang lain (Kompas, 24/5/2018). Secara kelembagaan, kepala daerah diusung oleh salah satu partai atau gabungan partai politik yang kemudian dalam melaksanakan tugasnya tidak sekedar melaksanakan tugas-tugas administrasi pemerintah daerah, akan tetapi juga mengemban amanah partai politik pengusung. Sementara secara legislasi (hukum) pemerintahan daerah dijabat oleh gubernur atau bupati terpilih, berasal dari salah satu partai atau gabungan partai politik yang diusung dalam pemilihan kepala daerah sehingga di dalam pengambilan keputusan kepala daerah cenderung dipengaruhi oleh kepentingan politik.

Melemahnya skema konteks sosial budaya, ekonomi dan geografis dalam proses kebijakan pendidikan pada pemerintahan daerah dikarenakan ketidakmampuan pejabat birokrasi pendidikan dalam mendeterminasi dan meyakinkan pejabat politik tentang pentingnya melihat permasalahan kondisi sosial budaya, ekonomi dan geografis masyarakat dalam peningkatan akses dan kualitas pendidikan. Pola relasi elit birokrasi dalam proses kebijakan pendidikan pada pemerintah daerah, birokrasi senantiasa menempatkan kepala daerah sebagai penguasa sehingga membuka ruang dan memudahkan kontrol elit politik terhadap birokrasi. Kondisi tersebut, tentu tidak terlepas dari pengaruh kepala daerah (Bupati) yang cenderung menempatkan kepentingan politik dan kekuasaan dalam pengambilan keputusan dalam mendesain proses kebijakan dan program pendidikan baik di level birokrasi maupun elit politik yang kemudian berimplikasi pada defisit kebijakan. Pengambilan keputusan dalam proses kebijakan pendidikan di daerah, senantiasa melibatkan kepentingan penguasa sebagai partai pemenang dan pendukung di dalam kontestasi kepala daerah. Hal ini terlihat dari distribusi jabatan dalam birokrasi pendidikan pada pemerintah daerah di Kabupaten Buton dan Buton Selatan baik di tingkat kepala dinas maupun di level kepala sekolah senantiasa di bawah kontrol kepala daerah (bupati). Sebagaimana kasus yang terjadi di daerah Kabupaten Buton Selatan menjelaskan bahwa sebagian besar kepala sekolah yang menjabat atas dasar rekomendasi dan kepentingan politik dalam proses kontestasi pemilihan bupati sebelumnya (Kadiknas Buton, 23 Januari 2018). Dinamika kebijakan desentralisasi bidang pendidikan merupakan bentuk kebijakan politik pemerintah melalui pendelegasian kewenangan pemerintah pusat kepada pemerintah daerah untuk membuat keputusan-keputusan yang berkenaan dengan upaya untuk memperbaiki kualitas pendidikan dan sumber daya manusia. Sistem pendidikan yang selama ini dikelola dalam iklim birokratis sentralistik dianggap sebagai salah satu penyebab terjadinya keterpurukan mutu pendidikan dan akses pendidikan di masyarakat. Hal ini beralasan karena sistem birokrasi selalu menempatkan "kekuasaan" sebagai faktor yang paling menentukan dalam proses 
pengambilan keputusan. Berbagai kebijakan pendidikan dewasa ini terus digulirkan pemerintah untuk mengatasi permasalahan sosial pendidikan di masyarakat, akan tetapi tak kunjung memberikan solusi akhir bahkan berbagai kebijakan publik sering kali menimbulkan persoalan baru di masyarakat. Salah satu persoalan kebijakan pendidikan hingga saat ini adalah disparitas pendidikan dan tidak meratanya akses pendidikan berkualitas di musyarakat, seakan berbagai program dan kebijakan pemerintah tidak pernah mampu menyelesaikan problematik pendidikan yang ada di masyarakat. Analisis kebijakan pendidikan menjadi penting dilakukan untuk memberi masukan dan kritik terhadap konten dan proses kebijakan, untuk membongkar masalah pendidikan yang terpinggirkan bahwa dampak kumulatif analisis tersebut dapat memperkuat gagasan bahwa kebijakan publik hanya untuk para elit (Morgan, Rein \& Goodin, 2015).

\section{KESIMPULAN}

Proses kebijakan pendidikan pada pemerintah daerah Kabupaten Buton dan Buton Selatan sejauh ini masih di determinasi oleh dua arus utama yakni elit struktural birokrasi dan elit politik. Proses kontestasi di tingkat elit struktur birokrasi menjadi tahap awal dominasi elit politik dalam proses kebijakan pendidikan di daerah. Dinas pendidikan selaku perpanjangan tangan dari kepala daerah untuk melaksanakan tugas dan fungsinya yang secara struktural di bawah kontrol Bappeda sehingga proses agenda setting kebijakan pendidikan senantiasa di bawah kendali kepentingan politik kepala daerah. Pembahasan program kerja antara dinas pendidikan dengan Bappeda sering kali berlangsung tidak sehat dan mengarah pada lobilobi untuk meloloskan program kerja dengan pertimbangan kebutuhan anggaran yang terbatas sehingga mengesampingkan program kerja yang telah rancang dan menjadi skala prioritas dinas pendidikan. Kontestasi proses kebijakan pendidikan di tingkat elit struktural birokrasi menjadi tahap awal terjadinya proses dominasi elit terhadap program kerja bidang pendidikan yang telah disusun oleh dinas pendidikan di daerah yang kemudian menimbulkan proses disparitas pendidikan di masyarakat.

Proses kontestasi kebijakan pendidikan pada pemerintah daerah tidak berhenti pada level struktur birokrasi melainkan berlanjut pada level yang lebih tinggi yakni kontestasi elit politik antara eksekutif dan legislatif. Kontestasi di tingkat elit politik menjadi tahapan yang sangat krusial dalam pembahasan paripurna kebijakan pendidikan pemerintah daerah. Hal menarik adalah sebelum pembahasan paripurna program kerja pemerintah daerah dilaksanakan, terlebih dahulu dilakukan komunikasi politik tentang pra pembahasan kebijakan pendidikan atas inisiatif legislatif dan eksekutif. Dalam proses komunikasi politik belakang panggung, tidak semua pejabat struktural pemerintah daerah dan anggota 
komisi legislatif terlibat dalam pertemuan pra pembahasan, melainkan hanya unsur pimpinan yang terlibat dan di rekomendasi oleh pimpinan DPRD atau kepala daerah (Bupati).

Diskursus pra pembahasan kebijakan dan program kerja pemerintah daerah di tingkat elit politik, cenderung mengarah pada pembahasan kepentingan eksekutif dan legislatif melalui pendekatan skala prioritas kebijakan dan program kerja, sumber dana, anggaran pemerintah daerah dengan tetap memperhatikan kepentingan legislatif dalam kebijakan program kerja pemerintah daerah. Sehingga ketika sampai pada tahapan diskursus pembahasan paripurna kebijakan dan program kerja pemerintah daerah berlangsung, perdebatan antara eksekutif dan legislatif berlangsung dalam kondisi standar atau biasa-biasa saja. Kalaupun dalam pembahasan paripurna masih terjadi perdebatan antara elit politik dan eksekutif sesungguhnya merupakan bagian dari drama politik sehingga proses pembahasan paripurna terlihat berjalan sesuai dengan mekanisme dan prosedur yang telah di rencanakan. Dominasi kepentingan elit politik dalam proses kebijakan pendidikan juga ditunjukkan dengan komitmen pemerintah daerah dan DPRD terhadap besaran anggaran pendidikan yang belum memenuhi ketentuan Undang-Undang Pendidikan Nomor 20 Tahun 2003 bahwa alokasi anggaran pendidikan minimal sebesar 20 persen dari APBD.

\section{REFERENSI}

Bakrey, Aminuddin. 2010. Kebijakan Pendidikan sebagai Kebijakan Publik. Jurnal MEDTEK, Vol. 2, No. 1, hlm. 1-13.

Bardhan, P. \& Mokherjee, D. 2005. Capture and Governance at Local and National Levels, American Economic Review, Vol. 90, No. 2, pp. 135-139.

Bell, Les \& Howard, Stevenson. 2006. Education Policy, Prosses, Themes and Impact, by Routledge, New York.

Bremen, Jan. 1997. Menjinakkan Sang Kuli, Politik Kolonial pada Awal Abad Ke-20, Jakarta: Pustaka Utama Grafiti.

Budge, I. \& H. Keman. 1990. Parties and Democracy: Coalition Formation and Government Functioning in Twenty State, London: Oxford University Press.

Cheema, G. Shabbir \& Dennis A. Rondinelli. 1988.

Decentralization and Development: Policy Implementation in Developing Countries, Beverly Hills, California: Sage.

Dorius, Shawn F. 2013. The Rise and Fall of Worldwide Education Inequality from 1870 to 2010 : Measurement and Trends, Sociology of Education, Vol. 86, No. 2 (April, 2013), pp. 158-173. Diakses melalui http://www.jstor.org/stable/43 186768. 
Dunn, William N. 1994. Public Policy Analysis an Introduction, Prentice Hall Inc. A Simon and Schuste Company Englewood Clift, New Jersey.

Dye, Thomas R. 2000. Understanding Public Policy, Perentice Hall, New York.

Dwiningrum, Irene Astuti. 2011. Desentralisasi dan Partisipasi Masyarakat dalam Pendidikan, Yogyakarta, Pustaka Pelajar.

Dwiyanto, Agus. 2005. Mewujudkan Good Governance: Melalui Pelayanan Publik, Yogyakarta, Gajah Mada University Prees.

Effendy, Muhadjir. 2016. Kesenjangan Pendidikan, diakses (1 Agustus 2016)

http://pojoksatu.id/pendidikan /2016/08/01/ini-3-

kesenjangan-pendidikanmenurut-mendikbud-muhadjir.

Fischer, Frank, Gerald J. Miller \& Mara S. Sidney. 2015. Handbook Analisis Kebijakan Publik. Teori, Politik dan Metode. Bandung, Penerbit: Nusa Media.

Grindle, MS. 2007. Going local: Decentralization,

Democratization, And The Promise of Good Governance. New Jersey: Princeton University Press.

Gunawan, Imam. 2010. Arah Politik Pendidikan Indonesia, diakses (April 2017) http://masimamgun.blogspot.c o.id/2010/05/arah-politikpendidikan-indonesia.html.

Howlett, Michael \& Ramesh, M. 1995. Studying Public Policy: Policy Cycles and Policy Subsystem, Canada: Oxford University Press.
Keban, Yeremias T. 2016. Enam Dimensi Strategis Administrasi Publik, Konsep, Teori dan Isu, Yogyakarta: Gava Media.

Lewis, Oscar. (1983). "Kebudayaan Kemiskinan"; Dalam Kemiskinan di Perkotaan, Jakarta: Sinar Harapan.

Lewis, Theodore. 2007. Social Inequality in Education: A Constraint on an American High-Skills Future, Vol. 37, No. 4 (Dec., 2007), pp. 329-349. Diakses melalui http://www.jstor.org/stable/30 053159.

Malley, M. S. 2003. New Rules, Old Structures and the Limits of Democratic Decentralisation, in Local Power and Politics in Indonesia: Decentralisation and Democratisation, eds E. Aspinall \& G. Fealy, Institute of Southeast Asian Studies, Singapore, pp. 102-116.

Montt, Guillermo. 2011. Crossnational Differences in Educational Achievement Inequality, American Sociological Association, Vol. 84, No. 1 (January, 2011), pp. 49-68. Diakses melalui http://www.jstor.org/stable/23 057035.

Morgan, Michael., Rein, Marti \& Goodin, Robert E. 2015. Handbook Kebijakan Publik. Bandung: Penerbit, Nusa Media.

Nguyen, Mai. 2011. Closing the Education Gap: A Case for Aboriginal Early Childhood Education in Canada, ALook at the Aboriginal Headstart 
Program. Canadian Journal of Education/Revue canadienne de l'éducation, Vol. 34, No. 3, pp. 229-248.

Nurzaman, S.S. 2002. Perencanaan Wilayah di Indonesai Pada Masa Sekitar Krisis, Bandung: ITB.

Paqueo V. \& Lammert. J. 2000. Decentarlization in Education. New York: Education Reform dan Management Thematic Group.

Parsons, Wayne. 2014. Public Policy: Pengantar Teori dan Praktik Analisis Kebijakan, Jakarta: Kencana.

Putra, Andika K. 2015. Resistensi Finlandia Terhadap Global Education Reform Movement, Journal Analisis Hubungan Internasional, Universitas Airlangga, Vol. 4. No. 1, hlm. 1393-1418.

Rohman, A. (2010). Education Policy In Decentralization Era, Yogyakarta: Pustaka Pelajar.

Surakhmad, Winarno 2009. Pendidikan Nasional, Strategi dan Tragedi, Jakarta: PT. Kompas, Media Nusantara.

Wahab, Abdul Solihin. 1991. Pengantar Analisis Kebijakan Negara, Jakarta: Sinar Grafika.

Wibowo, Udik Budi. 2015. Carut Marut Kebijakan Pendidikan di Indonesia, Proceeding National Seminar and International Confrence, Scientific ForumFaculty of Education \& Departement of Educational Science (FIP-JIP), pp. 502-509. 